\title{
Characterization of Pseudotachylite and Fault Gouges in Drill Cores from Andong, Korea and Its Implications for Paleo-Earthquakes
}

\author{
Chang Oh Choo ${ }^{1}$, Su Hyeon Jo ${ }^{2}$, , Sang-Youl Lee ${ }^{3}$, Sang-Eun Lee ${ }^{4}\left(\mathbb{D}\right.$ and Gyo-Cheol Jeong ${ }^{1, *}$ \\ 1 Department of Earth and Environmental Sciences, Andong National University, Andong 36729, Korea; \\ mineralogy@hanmail.net \\ 2 Department of Earthquake and Disaster Prevention Engineering, Andong National University, \\ Andong 36729, Korea; josh901103@naver.com \\ 3 Department of Civil Engineering, Andong National University, Andong 36729, Korea; lsy@anu.ac.kr \\ 4 Department of Energy and Mineral Resources Engineering, Kangwon National University, Samcheok 25913, \\ Korea; lee9367@kangwon.ac.kr \\ * Correspondence: jeong@anu.ac.kr; Tel.: +82-54-820-5753
}

Received: 18 November 2020; Accepted: 9 December 2020; Published: 13 December 2020

\begin{abstract}
Pseudotachylite and fault gouges were observed in core samples of Precambrian granitic gneiss drilled from depths as great as $1000 \mathrm{~m}$ in Andong, Korea. Fault gouges were found in the upper parts of the borehole, whereas pseudotachylites developed in the lower parts. Pseudotachylite with widths varying from a few $\mathrm{mm}$ to $10 \mathrm{~cm}$ sharply contacted or were interlayered with the host rock. The quartz-rich portion of the granitic gneiss remained unaffected, but the mafic portion was melted preferentially. The glassy surface of pseudotachylite is characterized by a smooth, glassy matrix with an amorphous phase and silicate beads with diameters of $\sim 200 \mathrm{~nm}$, together with slickenlines. Slickenlines composed of parallel grooves showed a wavelength of 4-7 $\mu \mathrm{m}$ and an amplitude $<1-2 \mu \mathrm{m}$. Residual or surviving grains have rounded corners and edges, indicating that those grains experienced abrasion, possibly from grain rotation or shear stress. Both melting and crushing contribute to the formation of pseudotachylite. Fe was always enriched in the glassy matrix, indicating that the pseudotachylite matrix originated from mafic minerals. The occurrence of pseudotachylite related to paleo-earthquake events showed that crystalline rocks in this area are unsatisfactory candidates for deep-disposal sites for high-level nuclear waste.
\end{abstract}

Keywords: pseudotachylite; fault gouges; glassy matrix; beads; slickenlines; paleo-earthquake

\section{Introduction}

Because pseudotachylite has been considered the unique product formed by paleo-earthquakes, it has important implications for subsequent fault behaviors and the stability of rock ground for high-level waste disposals. So far, pseudotachylite is considered very rare fault rock at outcrops in Korea, possibly because of its intrinsic mechanical properties (glassy, fragile; similar to obsidian or tachylite), which make it susceptible to subsequent alteration and weathering.

Pseudotachylite is characterized by its unique glassy or very finely crystalline material, and it occurs in fault zones and the rock adjacent to the fault zone when sliding of fault planes induces frictional melting during an earthquake [1-5]. Comminution of rocks and frictional heating during seismic faulting both contribute to the dissipation of stored energy in fault planes, leading frictional melts to form pseudotachylite [2]. Although there has been some controversy on the formation mechanisms and origins of pseudotachylite, it includes typically dark, glassy, amorphous veins or lump showing intrusive relation, and sharp boundaries as well as clasts and crystals of the host rock 
in the fault or shear zone [3]. Its formation is commonly controlled by fault-associated melting of the host rock in response to enough heat produced by major seismic slip events [4,5], though intense cataclasis by comminution of parent rocks is also important [5]. Because pseudotachylite forms through friction-induced melting along a fault surface during a major seismic slip [6,7], the occurrence itself has important implications for understanding paleo-earthquake or faulting activity.

Clay minerals in fractured zones are the alteration products of primary minerals or fine pulverized fragments of host rock from fault activity [8]. Fault gouges containing clay minerals correspond to secondary products that result from low-grade alteration or retrogressive metamorphism. Hence, the microstructural properties of these fractured rocks are closely related to the crystallization under faulting activity $[8,9]$. Therefore, fault gouges commonly include a significant amount of various clay minerals formed by faulting [10].

There have been more than twenty nuclear power plants operated in Korea since late 1970s. Nuclear energy takes up around $30 \%$ of the total electric power in Korea. For instance, its percentage of the total electric power has not been significantly changed: $31.3 \%$ in $2010,31.2 \%$ in 2015 , and $25.9 \%$ in 2019, respectively [11], although renewable energy sources instead of fossil fuel and nuclear energies have been increasingly sought since the 2010s.

Therefore, there have been growing concerns over securing stable sites for deep-ground disposals because the geology of Korea has quite complex lithology and has a long history ranging from Precambrian to Quaternary.

The purpose of the present study was to elucidate the microtextural features and mineralogical characteristics of fault rocks developed in drill holes, and, especially, to characterize pseudotachylite, with an emphasis on implications for paleo-earthquakes. For the present study, boreholes were drilled to a maximum depth of $1000 \mathrm{~m}$, as part of scientific site characterization for deep geological disposal of radioactive waste. Drill cutting, which may provide an important opportunity to collect the portions of host rocks directly related to faults at deep depths, has been widely used for the characterization of faults $[10,12,13]$.

\section{Geological Setting}

The area of interest for the present study is located about $5 \mathrm{~km}$ east of Andong city, middle Korea, with host rocks composed mainly of Precambrian gneiss with lesser amounts of amphibolite and Jurassic granite (Figure 1). The Precambrian gneiss belonging to the Yeongnam Massif is mostly granitic gneiss with slightly banded textures and weak foliations. In previous studies of the Andong area, the amphibolite was found to exhibit slight foliation and a minor banded structure, and the Jurassic granite was shown to vary in composition from tonalite to granite [14]. SHRIMP U-Pb age dating of zircon in the Jurassic granite batholiths intruding into the Precambrian metamorphic complex within the Yeongnam Massif has yielded ages of ca. 186 Ma [15].

The Andong Fault is known as one of the largest faults (longer than $50 \mathrm{~km}$ ) in the northern part of the Cretaceous Gyeongsang sedimentary basin. The fault is located approximately $2-3 \mathrm{~km}$ south of the study site. The Andong Fault System is characterized by the E-W trending boundary faults [16]. Nevertheless, there has been no evidence that the study site is in association with the Andong Fault. Moreover, no fault was found at the outcrops around the study site. 


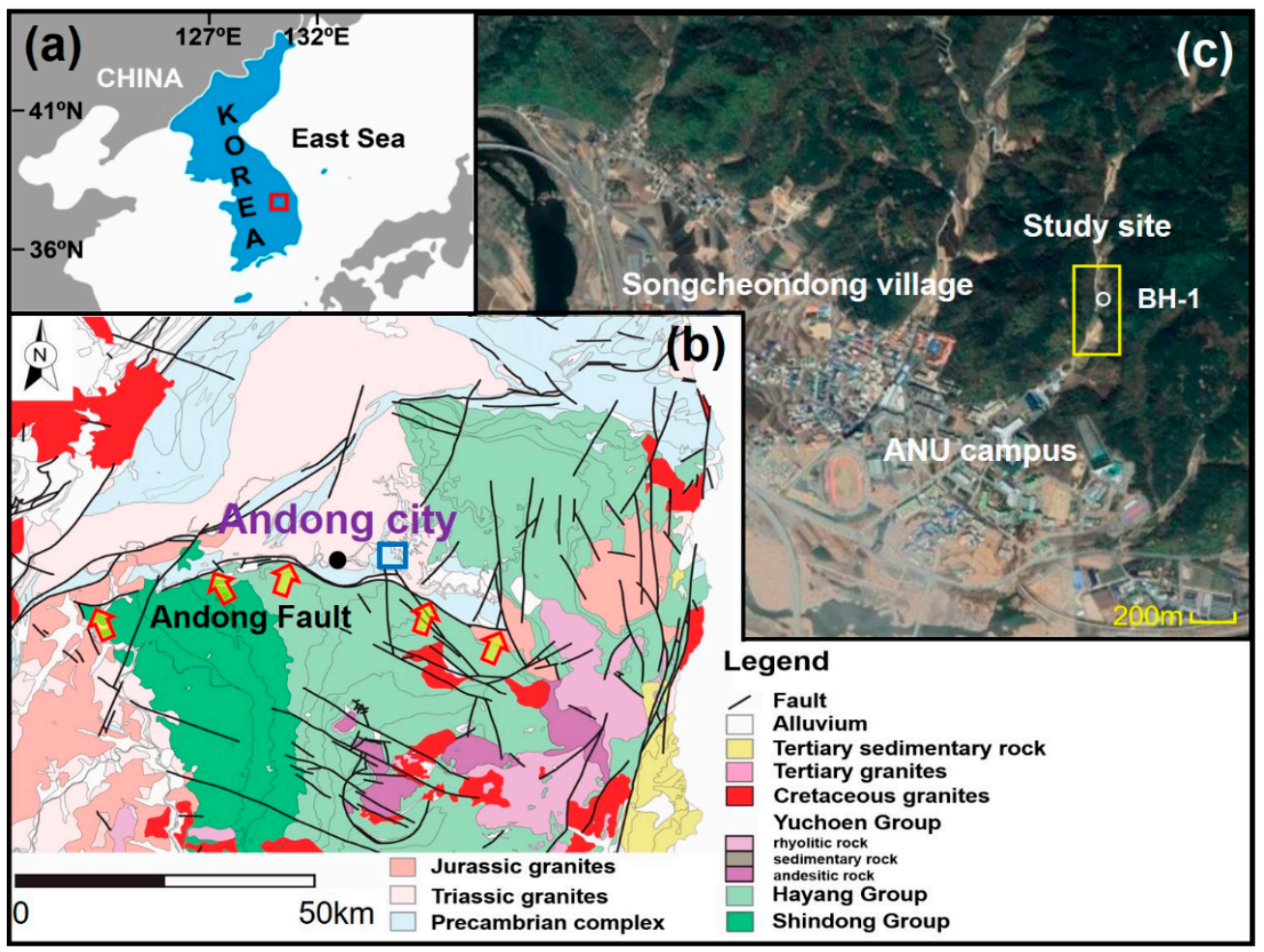

Figure 1. Site maps and geological map of the study area: (a) regional location map; (b) geological map of the study area (blue box) near Andong city, middle-eastern Korea (modified from a Korea geological map 1:1,000,000 by KIGAM); (c) the study site near Andong National University (ANU) campus is marked by a yellow box. BH-1 is the drilling site. Arrows indicate the whole distribution range of the Andong Fault. Left and right arrows represent the end points of Andong Fault. Middle arrows indicate some changes in fault directions.

\section{Materials and Methods}

For the present study, core samples were collected from the borehole drilled to a maximum depth of $1000 \mathrm{~m}$. The borehole site for core samples was located at a valley in the north, near the Andong National University (ANU) campus. In most cases, discontinuous structures developed in core samples included fault fractures, joints, fault gouges, and pseudotachylite. X-ray diffraction (XRD Ultima IV, Rigaku, Tokyo, Japan) analysis was performed on samples collected for fault gouges and pseudotachylite. The fault gouge samples were mainly composed of clay minerals with very fine-grain rock fragments. The following analytical conditions were used for the XRD analysis: a range of 5-65 $2 \theta$ at $40 \mathrm{kv} / 30 \mathrm{~mA}$ using an instrument equipped with a $\mathrm{Cu}$ target and Ni filter. After obtaining reflection data from powdered samples, we performed a quantitative analysis on the constituent minerals in the core samples using Siroquant v.3.0 (Sietronics in conjunction with CSIRO, Canberra, Australia), a quantitative analysis program based on the Rietveld method using diffraction patterns. In addition to this process, preferred orientation samples for XRD analysis were prepared to facilitate the identification of clay mineral species and basal spacings with specific $\mathrm{d}(00 l)$ peaks.

Microtextural observation and semi-quantitative chemical analysis were performed on untreated fresh portions of the core samples using scanning electron microscopy (SEM) equipped with energy dispersive spectroscopy (EDS). Field-emission SEM (FE-SEM) (S4200, Hitach, Tokyo, Japan) was applied to obtain microtextural images. The analytical conditions for FE-SEM observation were $20 \mathrm{kV}$ and $10 \mathrm{nA}$ using bulk samples coated with Osmium (Os) to avoid peak overlap among specific elemental spectra for the EDS analysis. These instrumental analyses were performed at the Daegu Center of the Korea Basic Science Institute (KBSI). 


\section{Results}

\subsection{Occurrence of Pseudotachylite and Fault Gouges in the Borehole}

The lithology of fault rocks identified in the core samples were mostly granitic gneiss with lesser amounts of felsic pegmatite intruding into the gneiss and amphibolite. Granitic gneiss is generally slightly greyish with medium- to coarse-grain quartz and feldspars. Although biotite is uncommon, it is slightly enriched relative to muscovite. Overall, gneissosity and foliation are weak or insignificant throughout the whole cores. Fault gouges and pseudotachylites, occurring randomly at various depths, were found in some samples recovered from the $1000 \mathrm{~m}$ drill cores (Figure 2). In general, fractured rocks were commonly found at shallower depths and fresh rocks were commonly found at deeper depths (especially >900 $\mathrm{m}$ with high rock quality designation (RQD) values (>95)). Fault gouges were found in the shallower parts of the borehole, whereas pseudotachylites had developed in the deeper parts. Pseudotachylites and fault gouge zones were commonly interlayered or closely associated with fault gouge [17-20]. Overall, the fractures or fault systems showed results of a kind of thrust fault gently dipping according to positions of pseudotachylite.

Fault gouges and strongly brecciated fault rocks occurred at depths of 98-99 m, 272 m, and 469 m, with most of their widths in the vertical sections being 5-10 cm. The fault gouges had different colors, textures, and thicknesses in the vertical sections. In particular, the fault gouges were gray, dark pink, and dark gray, indicating that the various fault gouges had formed under different physicochemical conditions at different stages of faulting.

The fault gouges in the core samples were mostly composed of clay minerals and fine-grain rock fragments (Figure 2). The rock fragments preserved in the host rocks coexisted with small particles derived from grain size reduction caused by pulverization of the host rocks during faulting. The pseudotachylite occurred locally at depths of 99, 466, 527, 530, 791, 799, and $882 \mathrm{~m}$ of the drill cuttings. Concordant or discordant glassy black veins of pseudotachylite were observed in association with gneissosity and foliation of the gneiss.

Pseudotachylite veins were irregular in form and thickness, ranging from a few $\mathrm{mm}$ to approximately $10 \mathrm{~cm}$ in cross section. The pseudotachylite occurred irregularly throughout the drill cores. The boundaries between each pseudotachylite and its host rock were irregular, either quite sharp or gradational. The boundary between the host rock and the fault zone including thin black layers was quite unclear, even at the microscopic scale [20]. Clumps of pseudotachylite or the glassy matrix was commonly homogeneous, but some included rock fragments or remnant crystals. The $530 \mathrm{~m}$ core depth pseudotachylite intruded into fault-fractured rocks and enclosed partial residual rock fragments. The pseudotachylite bands commonly had injection veins intruding the host rock. The most representative properties of the pseudotachylite at the depths of 791, 799, and $882 \mathrm{~m}$ was its glossy, glassy black textures. Some thin layers of pseudotachylite with a few $\mathrm{mm}$ thickness were locally developed in fractures as thin intrusions (Figure 2e,f).

The pseudotachylite occurred as black glassy clump or veinlets, as evidence of injection into fractures of the host rocks (Figure 3). For example, for core samples of pseudotachylite at 791-799 m depth in the drill hole, clumps of black glassy pseudotachylite with minor fold structures were in associated with remnant host rock. Pseudotachylite with widths varying from a few $\mathrm{mm}$ to $10 \mathrm{~cm}$ sharply contacted or was interlayered with the host rocks composed of Precambrian gneiss and amphibolite, indicating moderately ductile deformation. Some portions of pseudotachylite exhibited alternating textures with remnant host rock textures, indicating partial or selective melting. 


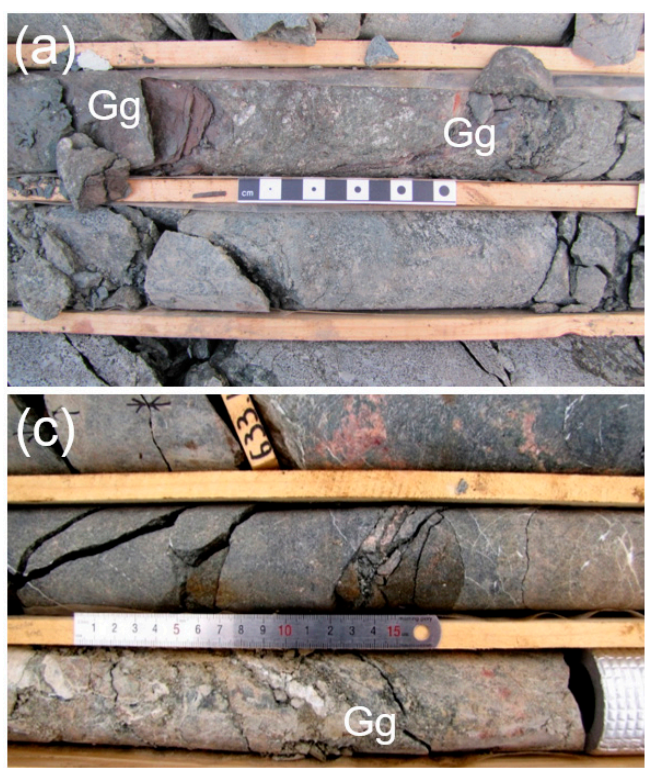

(e)

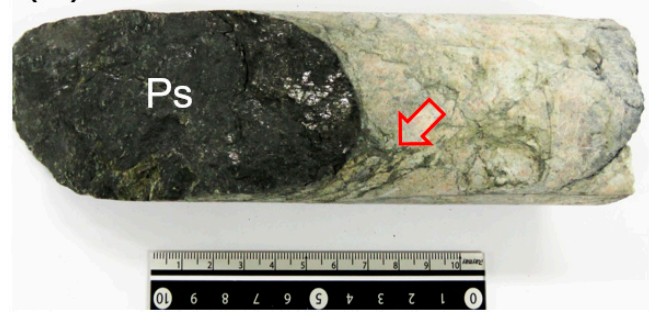

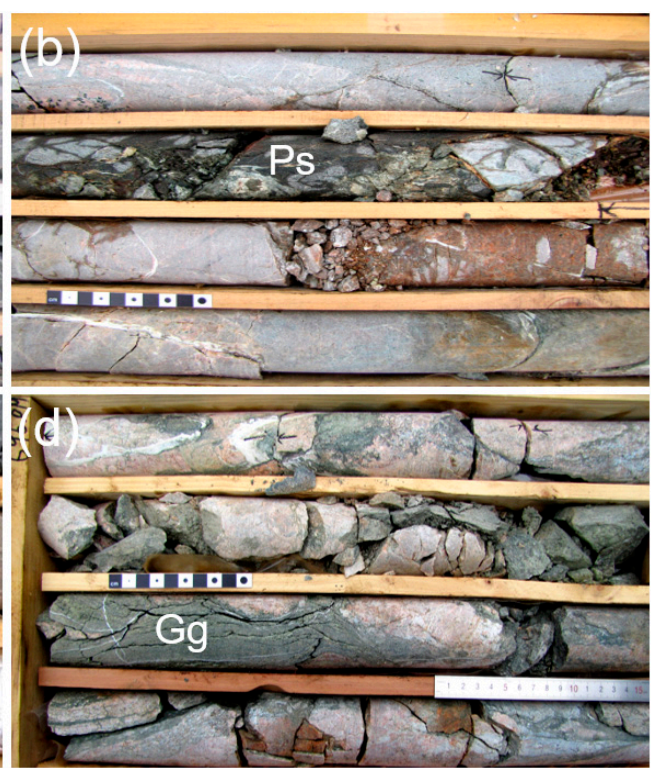

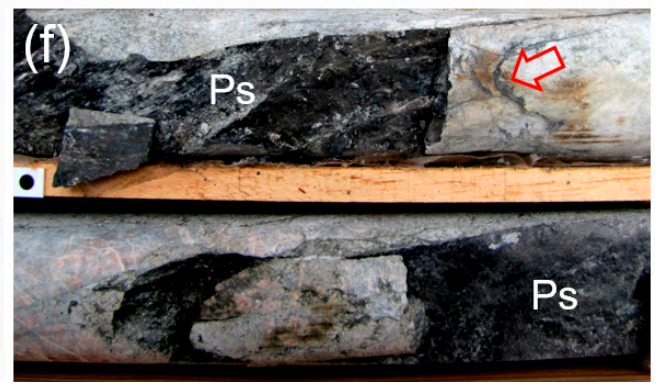

(g)
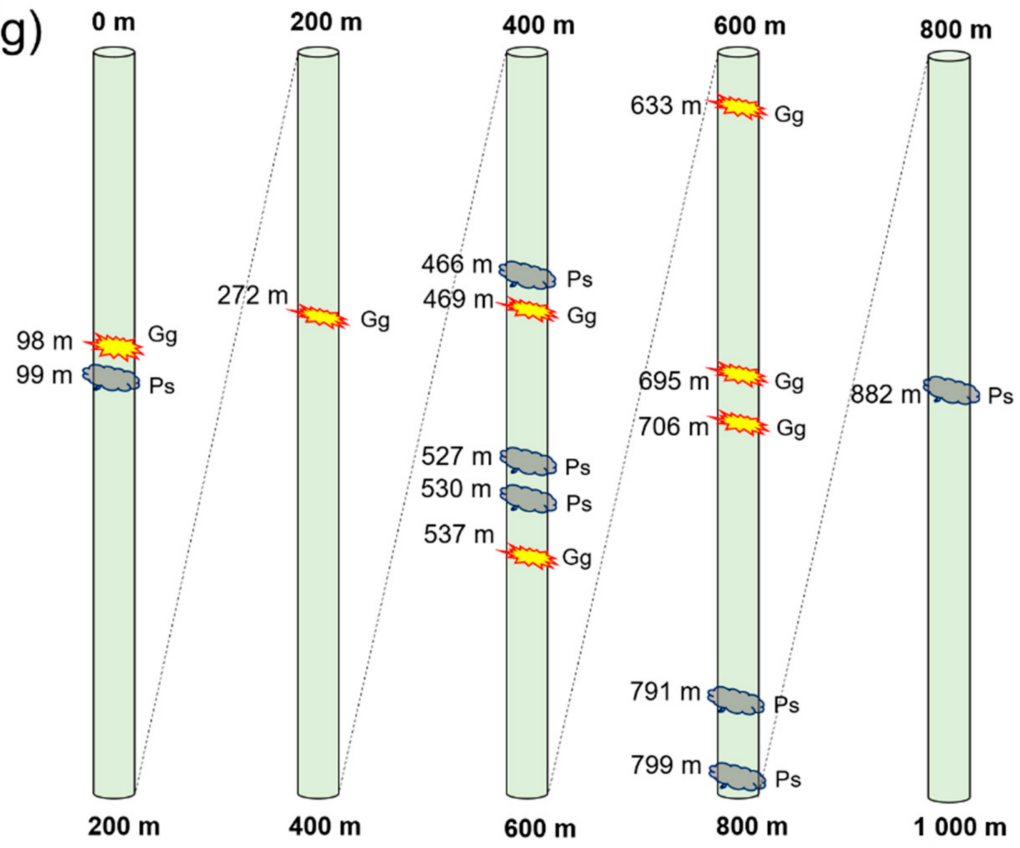

Figure 2. Representative core samples and schematic cross section of the borehole. All scale bars in core boxes are in cm. (a) Fault gouge (Gg) and fractured zone at $466 \mathrm{~m}$. (b) Pseudotachylite (Ps) at $530 \mathrm{~m}$. (c) Fault gouge (Gg) in brecciated rock at $633 \mathrm{~m}$. (d) Thick fault gouge (Gg) at $695 \mathrm{~m}$. (e) Pseudotachylite (Ps) at $791 \mathrm{~m}$. (f) Pseudotachylite (Ps) at $882 \mathrm{~m}$ showing black glassy texture. An arrow marks thin layer of pseudotachylite in fractures. (g) Schematic cross section of the borehole with fault gouge and pseudotachylite (not to scale). 

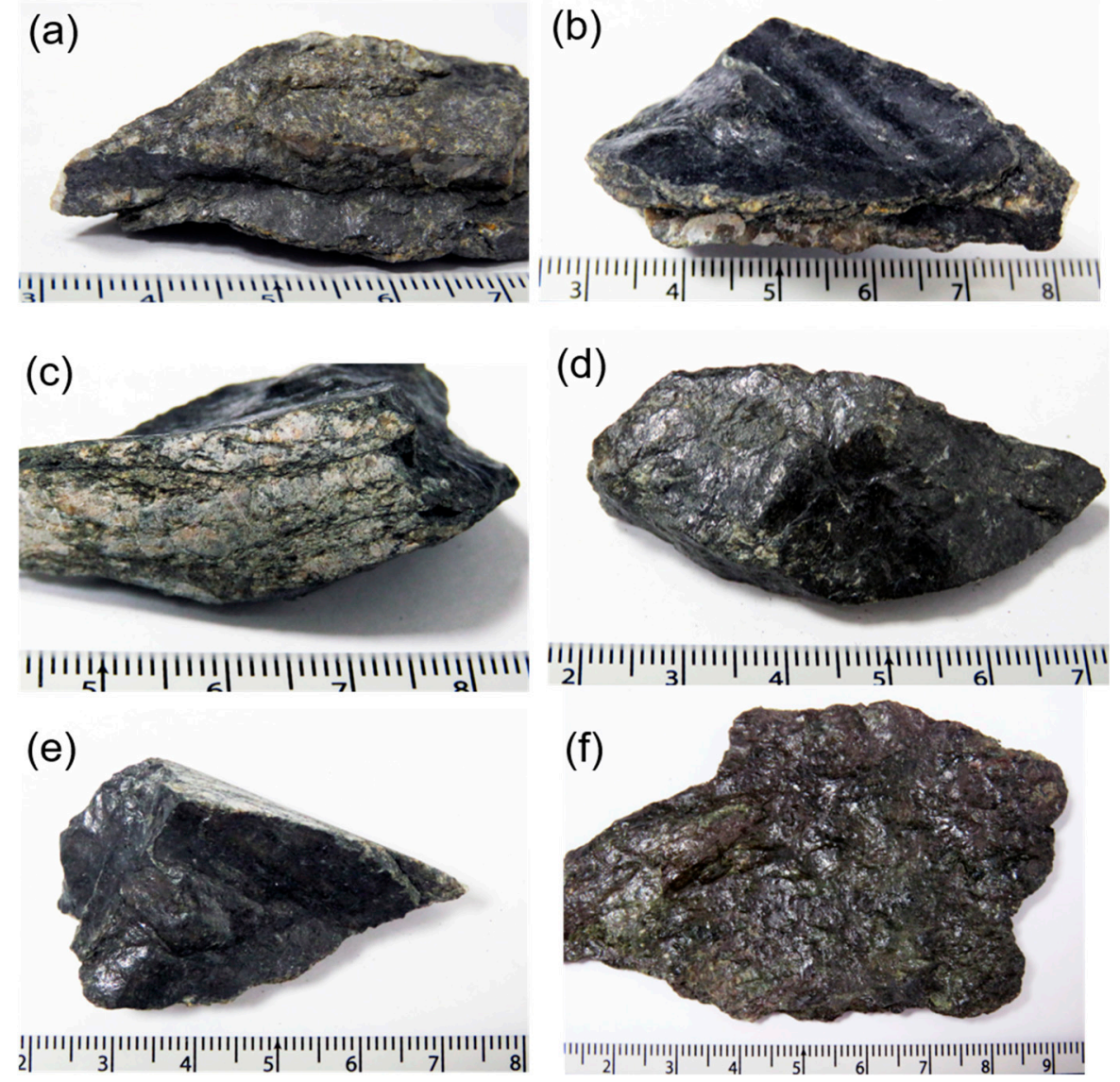

Figure 3. Representative samples of pseudotachylite: (a) remnant crystals are felsic minerals at $791 \mathrm{~m}$; (b) corrugated surface at $791 \mathrm{~m}$; (c) mafic veinlet and felsic remnants at $791 \mathrm{~m}$; (d) shiny greenish black clump at $791 \mathrm{~m}$; (e) shiny black clump at $791 \mathrm{~m}$; (f) rugged corrugation texture at $527 \mathrm{~m}$. All scales are in $\mathrm{cm}$.

The leucocratic part, including the quartz-rich part, of the granitic gneiss remained unaffected, whereas the mafic part was preferentially melted. That is, the quartz-rich part of the granitic gneiss was better preserved than the mafic part (Figure $3 a-c)$. A black glassy texture was typical of the pseudotachylite in the drill core samples (Figure 3d,e).

A rugged corrugation texture was exhibited by pseudotachylite in the $527 \mathrm{~m}$ core samples, indicating that there was partial melting or preferential melting of the host rock that left resistant materials behind (Figure 3f). In this case, the pseudotachylite was generally characterized by a smooth and glossy surface. However, some black parts were comparatively embossed and bore apophyses of 1-2 mm diameter on their surfaces, while dark green parts comprised the matrix. Although the pseudotachylite commonly appeared smooth and glassy, it was not always amorphous. For example, it was found that thin black layers of pseudotachylite were composed of clasts with various sizes and shapes randomly in an ultrafine matrix [20].

\subsection{Mineralogy of Pseudotachylite and Fault Gouges by XRD analysis}

Alteration minerals, including clay minerals and low temperature hydrous minerals, were commonly found in fault zones in the core samples. The mineral compositions, based on XRD quantitative analysis, of representative core samples composed of fault gouge and pseudotachylite varied with depths (Figures 4 and 5). Different reflections were associated with chlorite and vermiculite. For chlorite, the $d(001)$ reflection at $14.2 \AA$ was much weaker than the $d(002)$ reflection at $7.1 \AA$, whereas the $d(001)$ reflection of vermiculite was much stronger than the $d(002)$ reflection. The $d(006)$ reflection of chlorite was $1.502 \AA$ at $61.7^{\circ} 2 \theta$, indicating that the chlorite belonged to a trioctahedral type. 

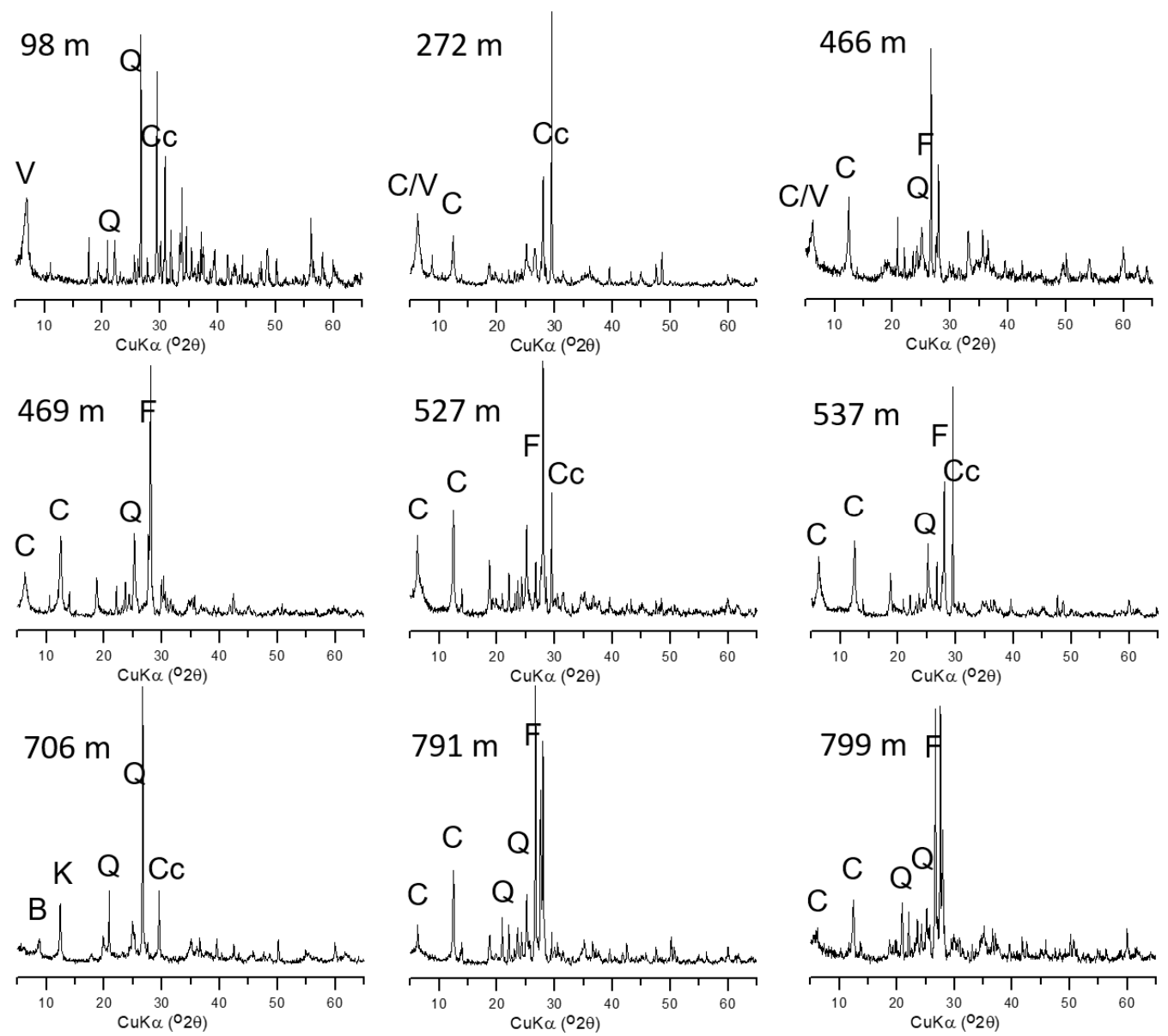

Figure 4. Powder X-ray diffraction patterns of representative bulk samples taken from borehole cores. C: chlorite; V: vermiculite; B: biotite; K: kaolinite; Q: quartz; Cc: calcite; F: feldspars (albite, orthoclase, microcline).

Based on quantitative XRD analysis, feldspars and quartz were the most abundant minerals among the rock-forming minerals in the core samples. The bulk gouge samples contained important primary minerals, including quartz (2.8-26.5\%), albite (6.0-53.6\%), microcline (5.8-25.3\%), orthoclase $(4.0-15.6 \%)$, and hornblende (5.0-7.9\%). The most abundant clay minerals in all gouge samples were chlorite, illite, kaolinite, and vermiculite. The content of secondary minerals such as calcite (1.4-64.4\%) and chlorite (4.7-44.3\%) were variable, and there were also some trace hydrous minerals, including clinozoisite (one of the most common epidote group species), goethite, and vermiculite, as well as other accessory minerals such as dolomite and garnet.

Especially $\mathrm{Fe}-\mathrm{Mg}$-rich clay minerals such as chlorite and vermiculite are products formed from mafic minerals, such as hornblende (one of the amphibole group) and biotite, as a result of water-rock interaction. These might have formed as secondary alteration products in close association with fault activity because these were not primary minerals in the granitic gneiss and amphibolite. Overall, the XRD spectra showed that no remarkable broad reflections were in the range of $20-40^{\circ} 2 \theta$, indicating little presence of amorphous silica. 


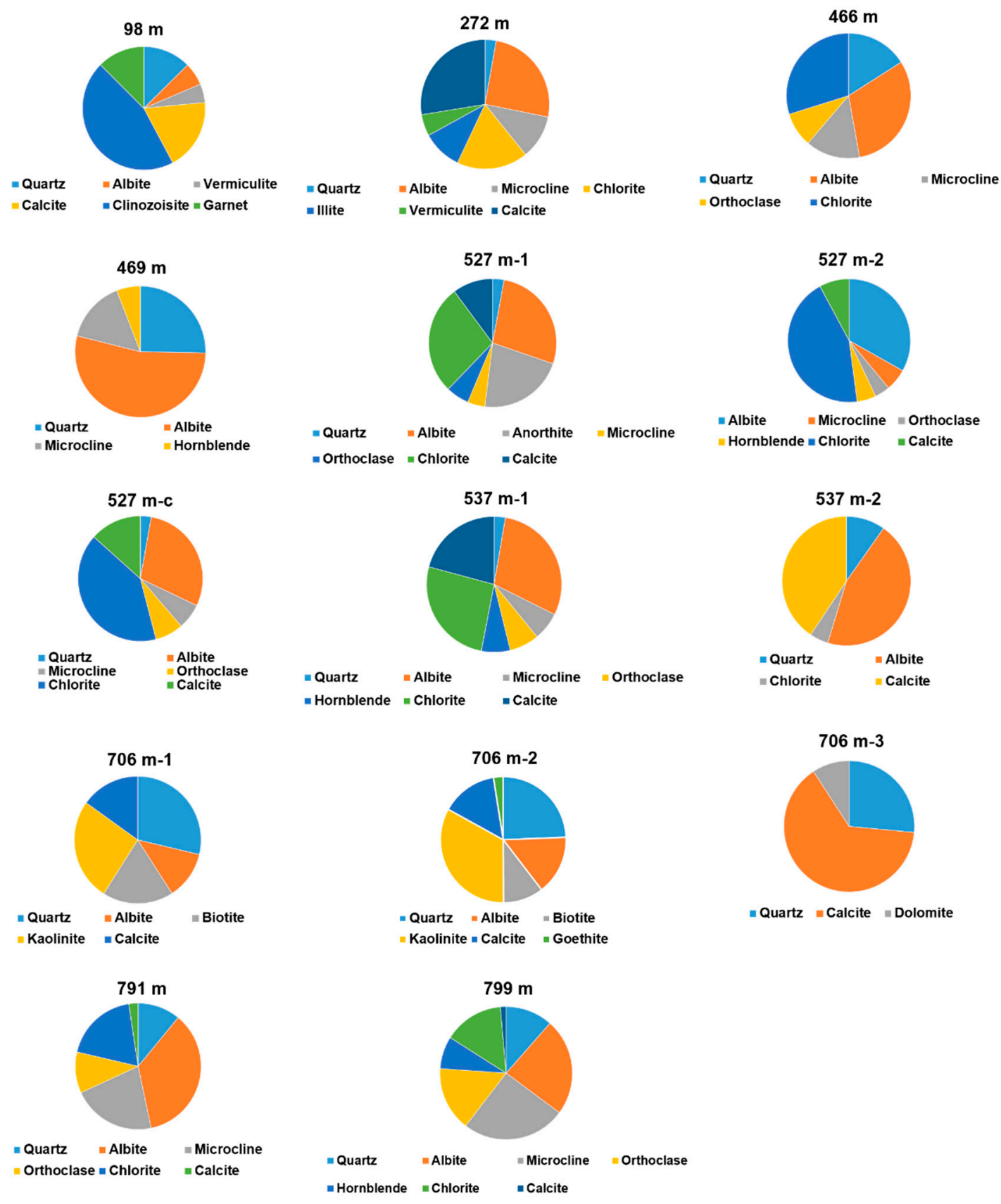

Figure 5. Mineral compositions (\%) of representative core samples composed of pseudotachylite and fault gouges were variable with depths, based on XRD quantitative analysis. Quartz and feldspars were predominant minerals while secondary minerals such as clay minerals and carbonates were less common. Fracture-filling carbonates were from the $706 \mathrm{~m}-3$ sample.

\subsection{Microtextural Characterization of Pseudotachylite and Fault Gouges by SEM}

\subsubsection{Pseudotachylite and Fault Gouges from Core Samples of 98-99 m}

In this section, the core samples showed properties of fault rocks with strong fragmentation. Quartz grains were commonly associated with some large fragments. Within the depth range of 98-99 m, fault gouges and pseudotachylite were developed in the fault rocks. The most common clay mineral in the fractured core samples was chlorite that had formed in close association with hornblende (Figure 6). 

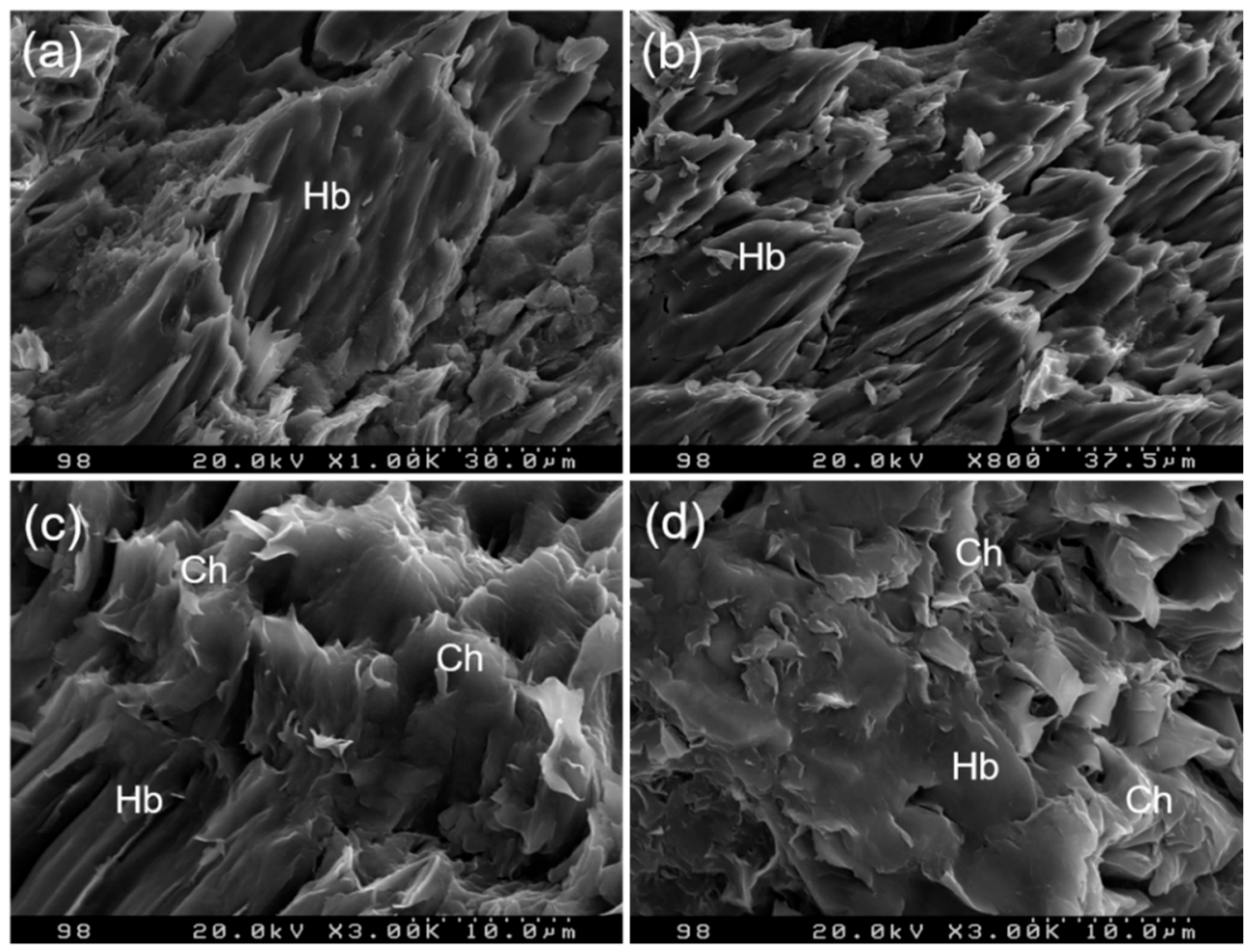

Figure 6. Scanning electron micrographs of the $98 \mathrm{~m}$ core samples showing hornblende alteration and newly formed chlorite. (a) Altered hornblende $(\mathrm{Hb})$ with inferred clay minerals. (b) Hornblende denticulation resulting from etching of crystals. Hornblende crystals narrowed toward tips. (c) Hornblende and chlorite $(\mathrm{Ch})$ aggregates. (d) Chlorite in association with altered hornblende.

One of the interesting points to be emphasized here is that the hornblende was characterized by denticulation texture. Such denticulation of hornblende remnants in dissolution cavities is common in alteration products during more advanced weathering [21-23]. It was found that denticulation on naturally weathered hornblende is formed by side-by-side coalescence of lenticular form [22,23], in which the tooth texture is arranged in parallel with the c-axis of the hornblende crystals because hornblende exhibits a prismatic habit with typical cleavages. Thin curled flakes on the tips of denticulation or etch pits on hornblende crystals are formed as secondary alteration minerals. Direct conversion of hornblende to chlorite was evidently observed. That is, the chlorite formed in association with denticulation on dissolved hornblende crystals, which indicates that the hornblende suffered intense dissolution followed by hydration. It seems that the denticulation of hornblende played a key role in the formation of secondary minerals, such as chlorite and mafic secondary minerals, through dissolution and hydration related to fault activity. Therefore, $\mathrm{Fe}$ and $\mathrm{Mg}$, the elements needed for chlorite formation, may be derived from hornblende.

At the depth of $99 \mathrm{~m}$, the pseudotachylite exhibited characteristic glassy surfaces and slight striations (Figure 7). Pseudotachylite with weak striations had a relatively rough surface with asperity (Figure 7a), and that with strong striations had an asymmetrical wave. Some pseudotachylites had weak striations in the glassy matrix. Striations were observed as partly asymmetrical waves with different wavelengths and amplitudes (Figure 7b). EDS analysis of the glassy matrix revealed typical compositions corresponding to $\mathrm{Fe}, \mathrm{Mg}$, and $\mathrm{Al}$ silicate compositions (Figure 7c,d), similar to the chemistry of hornblende. Residual fragments or welded glassy crystals had rounded boundaries against the glassy matrix, in which Ca levels were higher than in the glassy matrix (Figure 7d). Overall, Fe was more enriched in the glassy matrix of the pseudotachylite. 

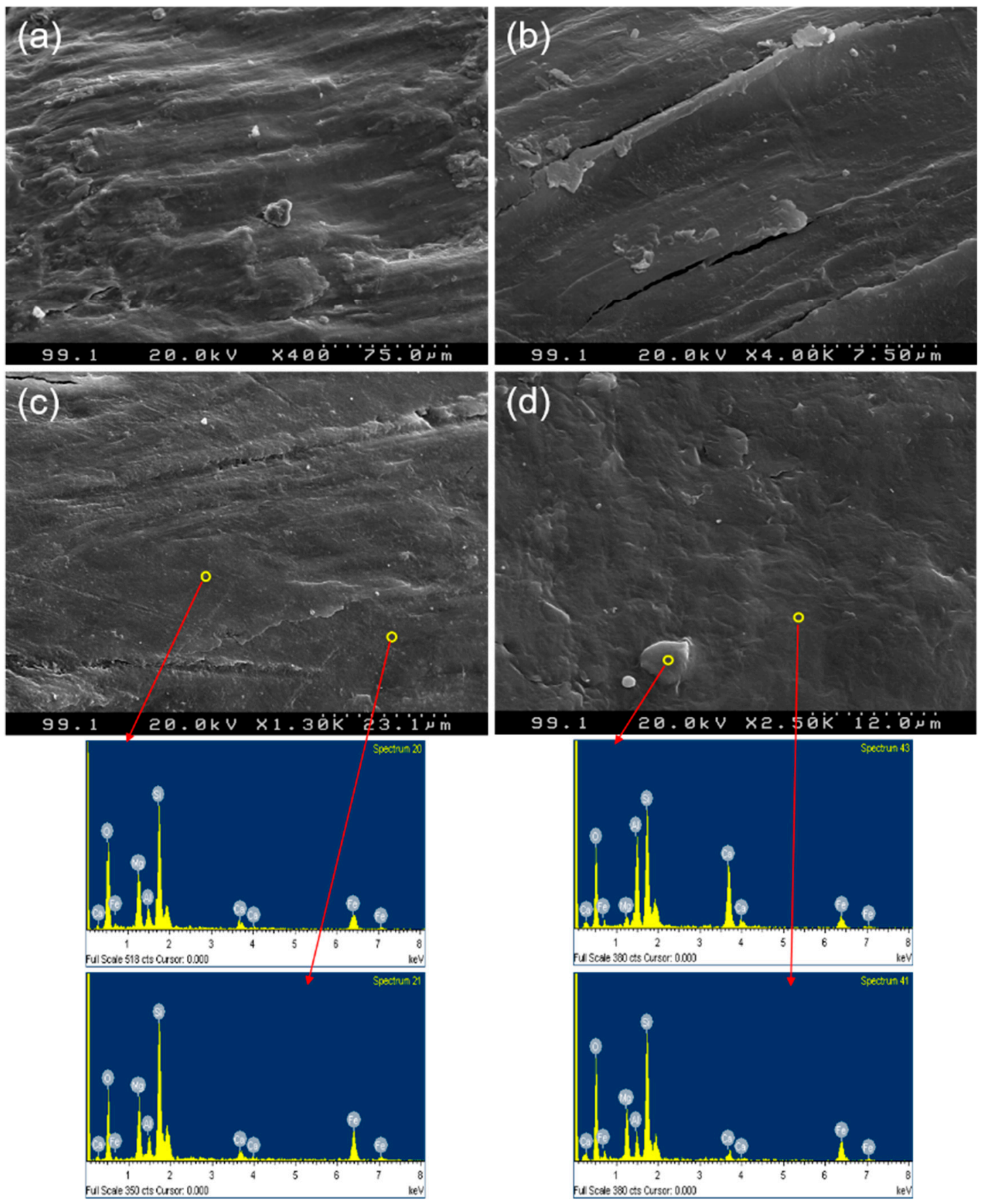

Figure 7. Scanning electron micrographs of the $99 \mathrm{~m}$ core sample showing pseudotachylite with glassy surfaces. (a) Weak striation and rough surface with asperity. (b) Strong striations with asymmetrical wave. (c) Weak striation and the glassy surface with energy dispersive spectroscopy (EDS) analysis points. (d) Residual fragments with rounded boundary on the glassy matrix with EDS analysis points. Fe is more enriched in matrix.

\subsubsection{Pseudotachylite from the $466 \mathrm{~m}$ Core Sample: Silica Beads and Slickenlines}

Amorphous beads of varying sizes, ranging from 100 to $400 \mathrm{~nm}$ in diameter, were commonly found in the pseudotachylite matrix in the $466 \mathrm{~m}$ core sample (Figure 8). The beads mostly had diameters of $\sim 200 \mathrm{~nm}$ [24]. A few amorphous beads in the matrix were spheroids or globules, but some came in other shapes-ellipsoidal or hemispheric apophyses emerging from the pseudotachylite matrix were common. 

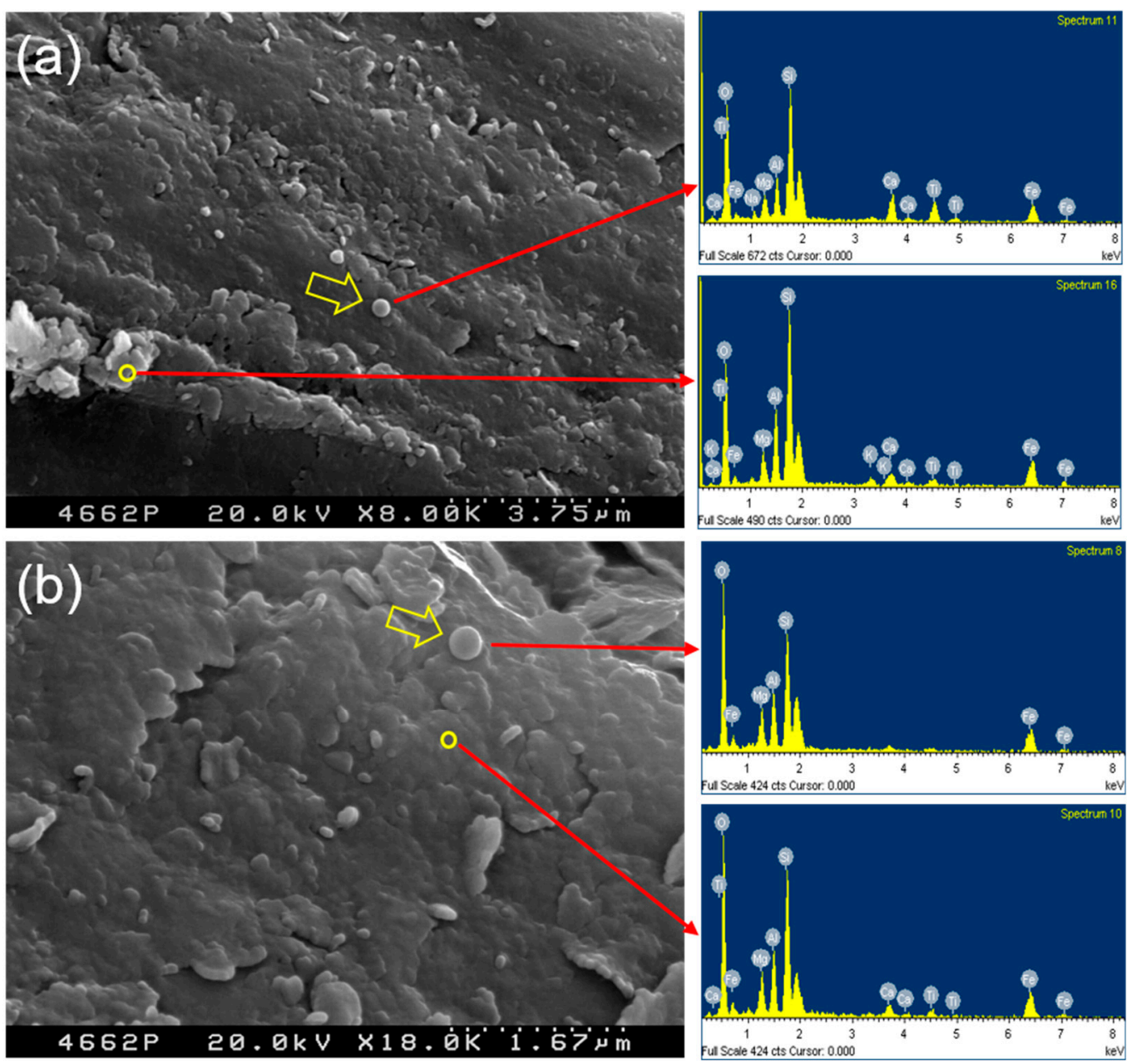

Figure 8. Scanning electron micrographs of the $466 \mathrm{~m}$ core sample showing pseudotachylite with amorphous beads on the glassy surfaces. (a) Amorphous spherical beads in the pseudotachylite matrix with corrugation or asperity. (b) Amorphous spherical beads formed on pseudotachylite surfaces. Some amorphous beads are ellipsoidal, hemispheric apophysis emerging from the pseudotachylite matrix. Beads have higher $\mathrm{Si}, \mathrm{Fe}$, and $\mathrm{Mg}$ than the glassy matrix.

According to the EDS analysis results, the spherical beads had slightly different compositions. Figure 8a shows semi-quantitative EDS data on the beads and matrix. As an example, one spherical bead had the following composition: Si 16.45, Al 5.14, Fe 7.63, Mg 3.45, Ti 5.41, Ca 4.68, and $\mathrm{Na}$ 1.83 wt.\%; whereas flat minerals had the following composition: Si 21.80, Al 8.99, Fe 11.62, Mg 4.21, Ti 1.42, Ca 1.90, and K 1.12 wt.\%, which is similar to the composition of biotite. Figure $8 \mathrm{~b}$ shows that amorphous spherical beads formed on pseudotachylite surfaces. The beads were composed of Si 18.09, $\mathrm{Al} \mathrm{8.13,} \mathrm{Fe} \mathrm{11.72,} \mathrm{and} \mathrm{Mg} 6.51 \mathrm{wt} \%$, whereas the glassy part was composed of Si 17.35, Al 7.50, Fe 10.57, $\mathrm{Mg}$ 5.37, Ti 1.49, and $\mathrm{Ca} 1.74 \mathrm{wt} \%$. The beads had higher $\mathrm{Si}, \mathrm{Al}, \mathrm{Fe}$, and $\mathrm{Mg}$ contents than the glassy matrix did.

In general, although the wavelength and amplitude of striations in the pseudotachylite matrix were not uniform or constant, they were mostly parallel to one another, forming well-developed slickenlines (Figure 9). In this study, slickenlines composed of parallel groves had wavelengths of $4-7 \mu \mathrm{m}$ and amplitudes of $<1-2 \mu \mathrm{m}$. 

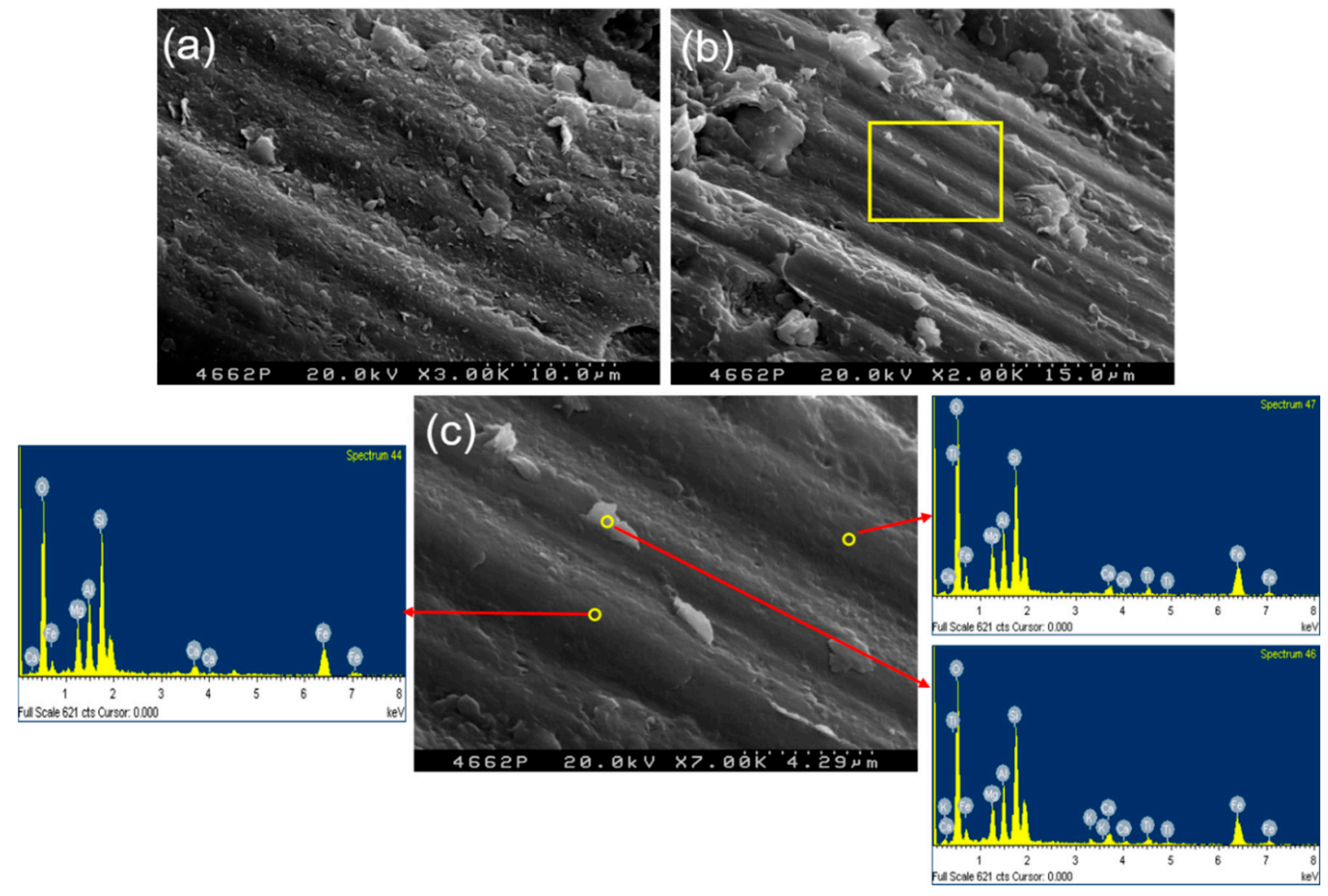

Figure 9. Scanning electron micrographs of the $466 \mathrm{~m}$ core sample and EDS analysis points marked as small circles in pseudotachylite. Slickenlines are composed of striations and groove on the pseudotachylite matrix at $466 \mathrm{~m}$ core sample. Striations and amorphous phase formed. (a) Slickenlines. (b) Well-developed slickenlines. (c) Enlarged image of the box area of (b). Flaky crystals on groove enriched in $\mathrm{K}$.

Asperity, including amorphous or poorly crystallized flaky minerals, was common on the pseudotachylite matrix, although their sizes varied. These features indicate that striations are related to ductile deformation. Some crystals on the matrix had high $\mathrm{K}$ and low $\mathrm{Fe}$, which is different from the composition of the matrix. These chemical features were consistent with the patterns of the pseudotachylite matrix (Figure 7). In other words, the pseudotachylite matrix had a higher Fe content than the crystals or fragments on the matrix did. Such a chemical pattern was always found in the pseudotachylite studied.

Because the direction of striation indicates the direction of movement along the fault plane, striations in slickensides are related to the principal slip zone (Figure 9a,b). At high magnification, rough glassy surfaces and some asperity were still observed in the pseudotachylite matrix, as shown in Figure 9c, likely due to slip that had occurred in a specific direction.

Amorphous minerals occurring as asperity growing on slickenlines seemed to have formed after the formation of the slickenlines (Figure $9 \mathrm{~b}$ ) because aggregates of amorphous minerals or grains were not affected by the striations. That is, these formed after the formation of the slickenlines.

\subsubsection{Pseudotachylite from the $527 \mathrm{~m}$ Core Sample}

At $527 \mathrm{~m}$, the pseudotachylite was generally characterized by a smooth, glassy surface (Figure 10). A partly rugged surface was common because of the presence of remnant or survived grains below the smooth surface (Figure 10a). Aggregates of survived grains were commonly observed where the smooth surface had been plucked out. Residual grains were embedded in the glassy matrix with a welding texture (Figure 10a,b). Notably, residual or survived grains had rounded corners or edges, indicating that those grains experienced abrasion, possibly due to grain rotation or shear stress, 
which implies frictional melting. Although the smooth surface was partly plucked out, striations on the glassy surface were common.
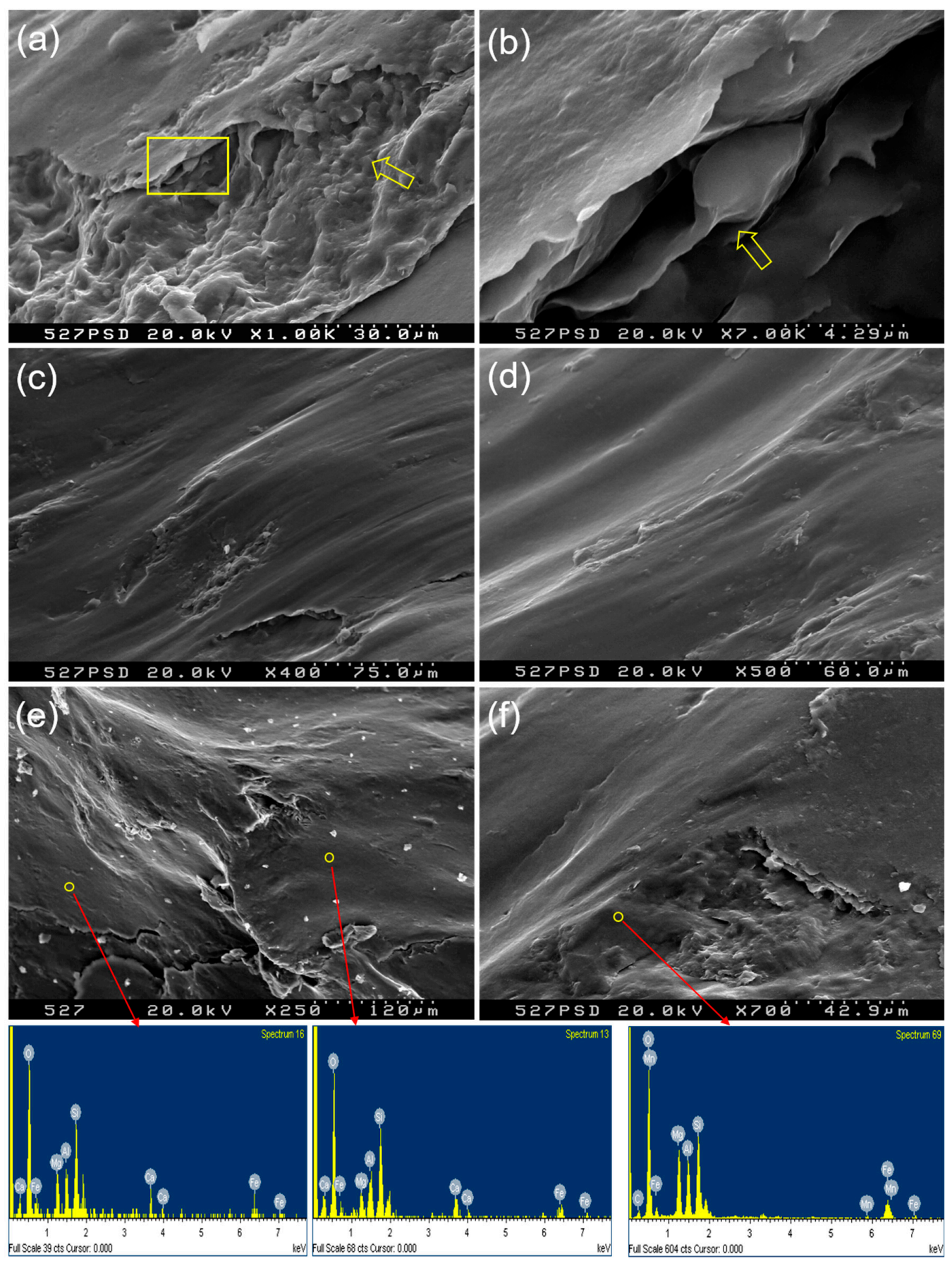

Figure 10. Scanning electron micrographs of the $527 \mathrm{~m}$ core sample showing glassy surface and EDS analysis points marked as small circles in pseudotachylite. (a) Smooth and plucked surface with survived grains with welding texture (arrowed area). (b) Enlargement of the box in (a). A survived grain surrounded by foliation and glassy surface. (c,d) The glassy matrix shows a smooth surface with weak striations. (e) Smooth surface and EDS analysis points marked as small circles. (f) Smooth surface with EDS analysis points marked as small circles.

The groove was quite weak, and wavelengths were non-constant or irregular (Figure 10c,d). The glassy surface was a very smooth surface with extremely low surface roughness. According to the typical chemical compositions of the smooth glassy surface of pseudotachylite as determined by EDS 
analysis, Fe, Mg, and Si were enriched in the glassy groundmass (Figure 10e). Welded grains had low Si contents in comparison with the glassy matrix (Figure 10f).

\subsubsection{Pseudotachylite from the $791 \mathrm{~m}$ Core Sample}

Some pseudotachylites showed asperity on smooth surface at the $791 \mathrm{~m}$ core (Figure 11). The glassy surface was relatively rough and there was slight wavy striation. It is likely that thin flaky layers were plucked out from the glassy matrix surface. As shown in Figure 11a, EDS results indicated that Si depletion and $\mathrm{Al}$ and $\mathrm{Mg}$ enrichment were observed in the glassy matrix, whereas Si enrichment and $\mathrm{Al}$ and $\mathrm{Mg}$ depletion were observed in the asperity part of welded fragments in the glassy matrix.
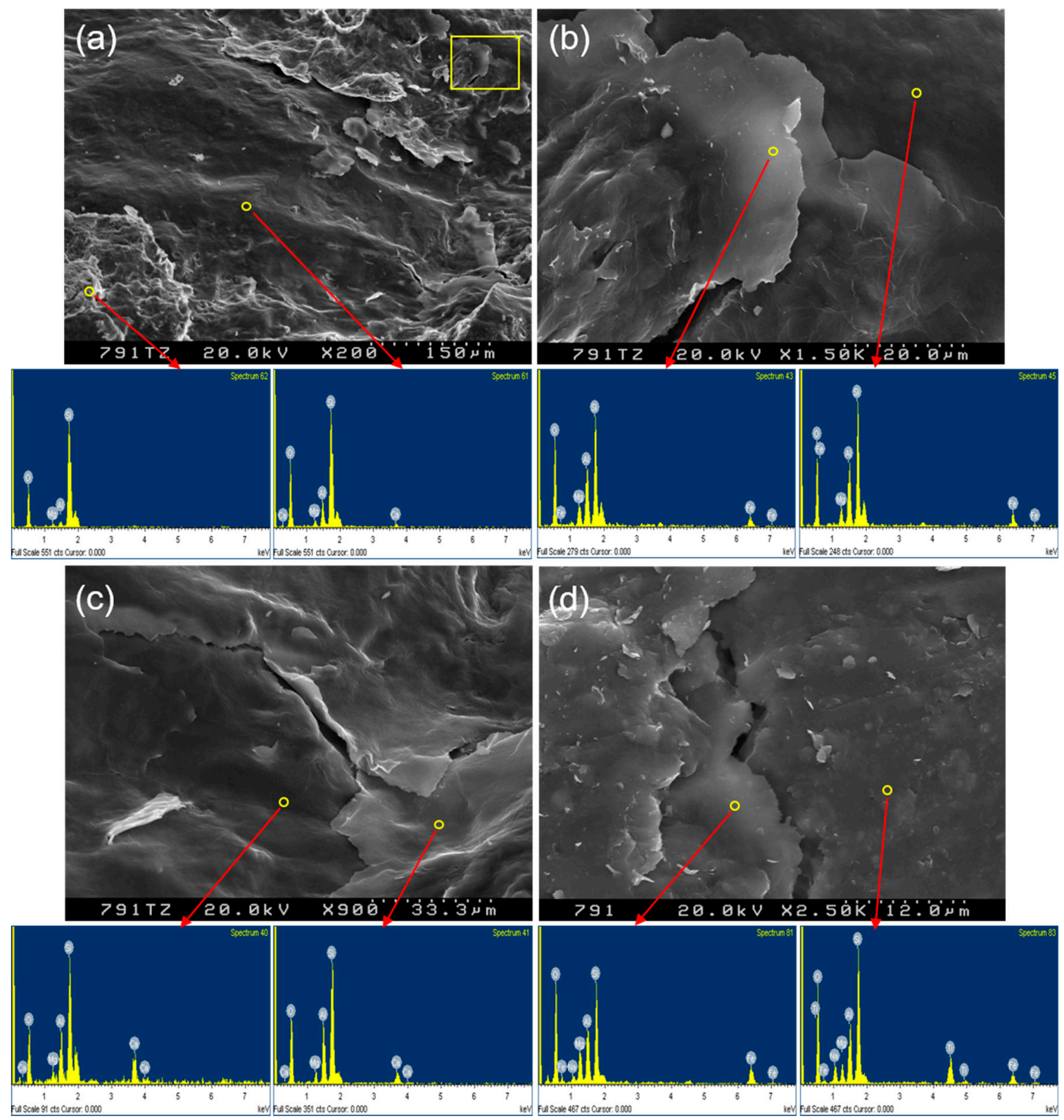

Figure 11. Scanning electron micrographs of the $791 \mathrm{~m}$ core sample and EDS analysis points marked as small circles in pseudotachylite. (a) Si depletion and Al enrichment in the matrix. (b) Enlarged image of the box area in (a). $\mathrm{Mg}$ and $\mathrm{Al}$ are enriched in thin flake (left), whereas $\mathrm{Si}$ and Fe are enriched in the glassy matrix (right). (c) Ca is enriched in the left part, whereas $\mathrm{Si}, \mathrm{Al}$, and $\mathrm{Mg}$ are enriched in the right part. (d) $\mathrm{Al}, \mathrm{Mg}$, and Fe are enriched in the left part, whereas $\mathrm{Ti}$ is enriched in the right. 
Thin glassy flakes were stripped off the glass matrix surface and became thinner toward the rim (Figure 11b). According to EDS results, Si and Fe were enriched in the glassy matrix, whereas they were depleted in thin glassy flakes. In addition, $\mathrm{Mg}$ and $\mathrm{Ca}$ were also detected in the glassy surface (Figure 11c). The glassy matrix had typical compositions, though there was some difference in analyzed points. $\mathrm{Fe}, \mathrm{Al}$, and $\mathrm{Mg}$ were enriched in the smooth surface (left point in Figure 11d), whereas they were depleted and Ti was enriched in the rough surface with asperity (right point in Figure 11d). In summary, Fe was always enriched in the smooth glassy surface of the pseudotachylite, which shows the same pattern observed in the other cases throughout the all core samples used in this study.

Asperity and welded glassy fragments were commonly found on rough surface (Figure 12). In the $791 \mathrm{~m}$ core sample, striation was poorly developed on smooth surface, and the groove pattern was quite shallow and obscure at low magnification (Figure 12a,b). The smooth surface commonly contained asperity. EDS results showed that flat crystals were enriched in $\mathrm{K}, \mathrm{Al}$, and $\mathrm{Ca}$, and they were depleted in Si (Figure 12c,d). Glassy fragments were generally welded and surrounded by the glassy matrix. Where they were plucked out, hollow cavities were commonly found. Hence, the glassy surface formed wavy or undulous relief.
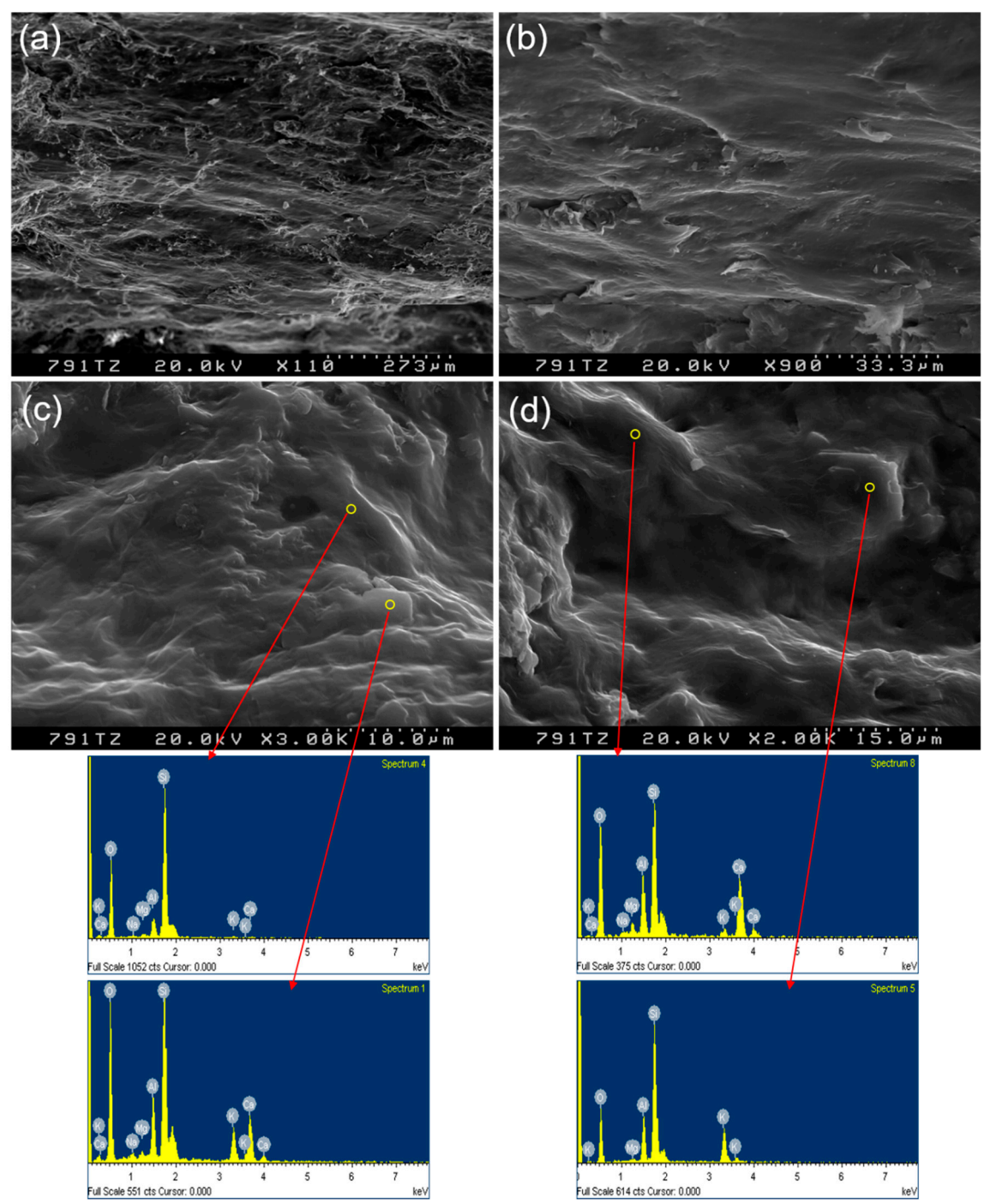

Figure 12. Scanning electron micrographs of the $791 \mathrm{~m}$ core sample showing welded glass fragments in pseudotachylite. (a) Slight striations and rough surface at low magnification. (b) Smooth surface with asperity. (c,d) Welded grains on glassy surface and EDS analysis points. Note flat grains as remnants and hollow cavities where grains were welded or removed out. 


\section{Discussion}

\subsection{Formation Conditions of Pseudotachlylite in the Borehole}

Most occurrences of pseudotachylite are interpreted to result from friction-induced melting accompanying co-seismic slips in brittle fault zones $[1,3,25,26]$, followed by rapid quenching at shallow depths during faulting [4]. However, though friction melting to produce pseudotachylite plays an important role in earthquakes, it is not easy to understand how pseudotachylite affects subsequent seismic stress [1,5,27-30]. Because pseudotachylite has weaker strength than the host rocks and it contains glassy characteristics in some parts, it is evident that pseudotachylite is susceptible to subsequent chemical alteration. Because the pseudotachylite in the study site preserved its own properties of glassy rocks, it did not experience intense alteration.

Partial melted part and residual grains or survived grains were present in the glassy matrix, characteristic of pseudotachylite. Judging from the various occurrences of pseudotachylite and fault gouges in the drill hole, it is evident that the fault rocks underwent multiple faulting or slip events under different stress regimes. Pseudotachylites preserved a variety of colors in different bands, indicating that they formed at different events or different degrees of earthquakes.

Multiple injection or vein arrays of pseudotachylite indicate that there was repeated strong rupturing for successive earthquakes [26]. In a broad sense, paleo-earthquakes took place periodically in this area; that is, multiple episodes of slip and the overprinting of successive deformation events took place.

It is common that the bulk chemistry of pseudotachylites is similar to that of the host rocks [31]. The composition of the pseudotachylite melt is affected by the mineralogy of host rocks, temperature, and the elapsed time between initial melting and final chilling [32-37]. The petrology of pseudotachylites derived from contrasting host rocks within the Alpine Fault of New Zealand observations suggest that pseudotachylite formation was strictly controlled by the mineralogy of the parent rocks [29].

Based on microstructural properties found in this study, it is evident that both melting and crushing contribute to the formation of pseudotachylite. Frictional melting and comminution of grains are complementary for pseudotachylite formation [28]. Because the physical properties of the constituent minerals highly affect the frictional melting, frictional melting of rocks involves selective melting of the mineral phases [30].

For instance, pseudotachylites are relatively common in rocks with a high content of mafic minerals [35]. It has long been acknowledged that pseudotachylites are at least partly molten during their formation $[3,4,28]$. In particular, the pseudotachylite here formed mainly via preferential or selective melting of mafic hydrous minerals rather than a simple melting of the host rocks $[37,38]$, consistent with the results in our study.

Each mineral has its own melting temperature as follows: biotite $\left(\sim 800^{\circ} \mathrm{C}\right)$, plagioclase $\left(\sim 1400^{\circ} \mathrm{C}\right)$, quartz $\left(\sim 1700{ }^{\circ} \mathrm{C}\right)$ [39], micas $\left(650^{\circ} \mathrm{C}\right)$, amphiboles $\left(750-1000^{\circ} \mathrm{C}\right)$, albite $\left(1100^{\circ} \mathrm{C}\right)$, K-feldspar $\left(1150^{\circ} \mathrm{C}\right)$, orthoclase $\left(1150^{\circ} \mathrm{C}\right)$, pyroxene $\left(1400^{\circ} \mathrm{C}\right)$, and anorthite $\left(1550^{\circ} \mathrm{C}\right)$, given by Spray [34]. Hence, it is assumed that maximum melting temperatures to produce pseudotachylite here were below melting temperatures of amphiboles—at most $750-1000{ }^{\circ} \mathrm{C}$.

The candidate minerals to form chlorite were amphibole and biotite contained in the Precambrian gneiss. In particularly, the chlorite formed from mafic minerals, mostly hornblende. Epidote is commonly associated with chlorite and mafic minerals [40], as was the case in this study. Calcium released by the breakdown of hornblende is commonly related to epidote [41]. Hydrous alteration minerals include chlorite, illite, and vermiculite. Carbonate minerals such as calcite and dolomite as veinlets or replacements of precursor minerals were due to fluid-rock interaction that occurred in fractured zones, with circulation of deep groundwater or thermal fluids.

The presence of clay minerals and hydrous mafic minerals significantly affects the formation of a melt during movement by faulting or earthquake [42]. For example, phyllosilicates and amphiboles such as hornblende take part in forming the melt phase, while silica-rich minerals such as quartz and 
feldspars remain unaffected to form survived clasts or remnants [38]. The depths at which seismic faulting relating to pseudotachylite takes place with the brittle-plastic transition are suggestive of the main temperature inducing faulting to form pseudotachylite and fault gouges [42-44]. Hornblende dissolution commonly occurs via a hydration process that forms alteration products such as chlorite and vermiculite $[45,46]$. Chlorite is one of the most common clay minerals, occurring in various rocks under low temperatures up to $350^{\circ} \mathrm{C}[47,48]$. Lin [38] estimated that the temperature of country rocks from the Fuyun fault zone in northwest China was around $300^{\circ} \mathrm{C}$ before the formation of pseudotachylite, possibly during a retrogressive stage after a main peak event. Considering such depths of $10-15 \mathrm{~km}$ and the alteration mineral assemblages of chlorite and epidote, the temperature of country rocks before the formation of pseudotachylite can be estimated to be at least about $300{ }^{\circ} \mathrm{C}$. It was suggested that pseudotachylites form at either relatively shallow or deep depths $(1.5-20 \mathrm{~km})[35,38,39,43]$.

\subsection{Origin of Silica Beads and Slickenlines in the Pseudotachylite Matrix}

Formation of silica beads as well as a microcrystalline or a nanocrystalline silica-rich groundmass observed in the pseudotachylite matrix strongly suggests the rapid crystallization from a melt with large undercooling [49]. The fact that crystalline silica has rounded cores included in the amorphous silica matrix [25] indicates that they are genetically interrelated. The rounded and embayed clasts in the pseudotachylite matrix likely originated from melting rather than crushing [4,24,50-53]. Silica beads formed through precipitation from amorphous silica phase may induce slip weakening and smoothing of fault surfaces such as fault mirrors [24].

The surface materials formed on the slickenside consist of microcrystalline $(0.01-1.0 \mu \mathrm{m})$ quartz with small amounts of iron oxide and clay minerals such as kaolinite [54]. Nano- to micro-scale friction processes are important because they may affect dynamic weakening during large earthquakes along faults [55].

Formation of amorphous silica phases and slickenlines on fault planes contributes to softening strain under shallow depth during fault slip $[25,35,55]$. Slickenside surfaces formed at quite shallow depths (less than $\sim 2 \mathrm{~km}$ ) and low temperatures (below $270{ }^{\circ} \mathrm{C}$ ) along the fault zone in the Dixie Valley area of central Nevada, USA [54]. Microcrystalline silica grains are also found in fault mirrors. For instance, aggregates of $\sim 1 \mu \mathrm{m}$ platy silica occur in borehole samples from the active Hsiaotungshi reverse fault (Taiwan) [56], which is similar to our results.

Formation mechanisms for the amorphous silicates are complex and various, involving chemical reactions, mechanical deformation, and quenching after frictional melting [57-62].

Amorphous beads developed in the glassy matrix of pseudotachylite indicate that supercooling or a rapid drop in temperature occurred during the retrograde stage after frictional melting. Amorphous spherical beads in the pseudotachylite matrix were associated with corrugation or asperity. In summary, beads on the pseudotachylite matrix or striations seem to have formed from rapid precipitation from melts, rather than from grain pulverization or comminution.

\subsection{Implications of Pseudotachylite for Paleo-Earthquakes}

Although the Korean peninsula has been quite stable compared to other countries due to its tectonic position, i.e., at the margin of the Eurasian continent, historical evidence of seismicity indicates that many earthquakes took place in the Korean peninsula, especially in its southeastern part [63-65]. In recent years, the total number of earthquakes in Korea were 252 in 2016, 223 in 2017, and 115 in 2018. Moreover, earthquakes with a magnitude larger than 4.0 occurred several times: four times in 2016, twice in 2017, and once in 2018. The M 5.8 Gyeongju earthquakes in September 2016 and the M 5.4 Pohang earthquake in November 2017 near the Yangsan fault system [66-68], which is the largest and most active Quaternary fault in the Korean peninsula, induced worrisome effects and caused serious damage to Korean society. In addition, earthquakes or earthquake-related land sliding induced landslides in areas with steep slopes or mountain areas susceptible to topographic effects. A series of such seismic events in Korea led to the opening of a new era of fault-related research, 
including fault activities, deep underground disposal, rock stability, and fault rocks, with consideration of paleo-earthquakes that had occurred throughout the Korean peninsula.

Although important information on the fault zone materials can be obtained from drilling projects, the results from a drilling site do not represent whole patterns of the fault zone due to a localized area and limited core samples [69]. Deep drill cuttings in this study showed that Precambrian metamorphic rocks in this area are unsatisfactory candidates for deep-disposal sites for high-level nuclear waste. Besides, fault mirrors are good indications for paleo-earthquake because they form as products of high temperature processes within fault zones [70].

In Korea, site characterization for deep geological disposal of nuclear waste has been performed as preliminary analyses considering the International Atomic Energy Agency (IAEA) recommendations, particularly favoring crystalline rocks for an underground research laboratory (URL) in South Korea, such as the Korea Atomic Energy Research Institute Underground Research Tunnel (KURT), built for investigations into the geological disposal of high-level radioactive waste [71,72]. The structural relation between the Andong Fault and the study area still remains unclear. Although no active fault has been observed in outcrops of the study area, age dating for pseudotachylite and fault gouges needs to be performed to determine whether the fault zones in the drilled site are active.

\section{Conclusions}

The pseudotachylites and fault gouges are slightly different in texture and thickness at random intervals at depths, indicating that faulting events occurred several times through different stages. Partially melted parts and residual grains or survived grains were present in the glassy matrix. Residual or survived grains had rounded corners or edges, indicating that those grains experienced abrasion possibly due to grain rotation or shear stress, which implies frictional melting. Beads on the pseudotachylite matrix or striations seem to have formed from rapid precipitation from melts. In this study, both melting and crushing contributed to the pseudotachylite formation. Because Fe was always enriched in the glassy matrix, it was evident that the pseudotachylite matrix originated from the melting of mafic mineralogy in the host rocks. The occurrence of pseudotachylite related to paleo-earthquake events showed that crystalline rocks in this area are unsatisfactory candidates for deep disposal sites for high-level nuclear waste. In rock mechanics, smooth characteristics of the glassy pseudotachylite play an important role in sliding and friction of faults by lowering friction force if strong stress is imposed on fault planes in drilling sites. Therefore, candidate sites for deep geological repositories for spent nuclear fuel or high-level nuclear waste in Korea should be further systematically evaluated, based on the goal that such sites are stable and free of paleo-earthquakes, weak rock mass, and glassy materials such as pseudotachylite.

Author Contributions: Conceptualization, data analysis, and writing, C.O.C.; data analysis and methodology, S.H.J., S.-Y.L., and S.-E.L.; writing-review and editing, G.-C.J. All authors have read and agreed to the published version of the manuscript.

Funding: This work was supported by the Korea Environmental Industry \& Technology Institute (KEITI) through the Surface Soil conservation and management (SS) Project, funded by the Korea Ministry of Environment (MOE) (2020002840003).

Acknowledgments: The authors would like to express thanks for the support of the Korea Environmental Industry \& Technology Institute (KEITI) and the Korea Ministry of Environment (MOE).

Conflicts of Interest: The authors declare no conflict of interest.

\section{References}

1. Philpotts, A.R. Origin of pseudotachylites. Am. J. Sci. 1964, 262, 1008-1035. [CrossRef]

2. Lavallée, Y.; Hirose, T.; Kendricka, J.E.; Hess, K.-U.; Dingwell, D.B. Fault rheology beyond frictional melting. Proc. Natl. Acad. Sci. USA 2015. [CrossRef] [PubMed]

3. Sibson, R.H. Generation of pseudotachylite by ancient seismic faulting. Geophys. J. R. Astr. Soc. 1975, 43, 775-794. [CrossRef] 
4. Maddock, R.H. Melt origin of fault-generated pseudotachylites demonstrated by textures. Geology 1983, 11, 105-108. [CrossRef]

5. Wenk, H.R. Are pseudotachylites products of fracture or fusion? Geology 1978, 6, 507-511. [CrossRef]

6. Magloughlin, J.F.; Spray, J.G. Frictional melting processes and products in geological materials: Introduction and discussion. Tectonophysics 1992, 204, 197-206. [CrossRef]

7. Di Toro, G.; Pennacchioni, G.; Nielsen, S. Pseudotachylites and earthquake source mechanics. In Fault-Zone Properties and Earthquake Rupture Dynamics; Fukuyama, E., Ed.; Elsevier Academic Press: Burlington, MA, USA, 2009; pp. 87-133.

8. Song, S.J.; Choo, C.O.; Chang, C.J.; Jang, Y.D. A microstructural study of the fault gouge in the granite, Yangbuk, Gyeongju, southeastern Korea, with implications for multiple faulting. Geosci. J. 2017, 21, 1-19. [CrossRef]

9. Rutter, E.H.; Maddock, R.H.; Hall, S.H.; White, S.H. Comparative microstructures of natural and experimentally produced clay-bearing fault gouges. Pure Appl. Geophys. 1986, 124, 3-30. [CrossRef]

10. Solum, J.G.; Hickman, S.H.; Lockner, D.A.; Moore, D.E.; van der Pluijm, B.A.; Schleicher, A.M.; Evans, J.P. Mineralogical characterization of protolith and fault rocks from the SAFOD main hole. Geophys. Res. Lett. 2006, 33, L21314. [CrossRef]

11. Statistics of Korea Government Official Work Conference. The Statistics of Electric Power in Korea. Available online: https://www.index.go.kr/potal/main/EachDtlPageDetail.do?idx_cd=1339 (accessed on 15 November 2020).

12. Otsuki, K.; Uduki, T.; Monzawa, N.; Tanaka, H. Clayey injection veins and pseudotachylite from two boreholes penetrating the Chelungpu Fault, Taiwan: Their implications for the contrastive seismic slip behaviors during the 1999 Chi-Chi earthquake. Island Arc 2005, 14, 22-36. [CrossRef]

13. Morrow, C.; Solum, J.; Tembe, S.; Lockner, D.; Wong, T.-F. Using drill cutting separates to estimate the strength of narrow shear zones at SAFOD. Geophys. Res. Lett. 2007, 34, L11301. [CrossRef]

14. Cheong, C.-S.; Kim, N. Review of radiometric ages for Phanerozoic granitoids in southern Korean peninsula. J. Petrol. Soc. Korea 2012, 21, 173-192. [CrossRef]

15. Yoon, R.; Song, Y.-S.; Yi, K. SHRIMP U-Pb zircon ages of the Yeongju and Andong Granites, Korea and their implications. J. Petrol. Soc. Korea 2014, 23, 209-220. [CrossRef]

16. Choi, P.Y.; Lee, S.R.; Choi, H.-I.; Hwang, J.-H.; Kwon, S.-K.; Ko, I.-S.; An, G.O. Movement history of the Andong Fault System: Geometric and tectonic approaches. Geosci. J. 2002, 6, 91-102. [CrossRef]

17. Sibson, R.H.; White, S.H.; Atkinson, B.K. Structure and distribution of fault rocks in the Alpine fault zone, New Zealand. Geol. Soc. Lond. Spec. Pub. 1981, 9, 197-210. [CrossRef]

18. Lin, A.; Shimamoto, T.; Maruyama, T.; Sigetomi, M.; Miyata, T.; Takemura, K.; Tanaka, H.; Uda, S.; Murata, A. Comparative study of cataclastic rocks from a drill core and outcrops of the Nojima Fault zone on Awaji Island, Japan. Island Arc 2001, 10, 368-380. [CrossRef]

19. Buatier, M.D.; Chauvet, A.; Kanitpanyacharoen, W.; Wenk, H.R.; Ritz, J.F.; Jolivet, M. Origin and behavior of clay minerals in the Bogd fault gouge, Mongolia. J. Struct. Geol. 2012, 34, 77-90. [CrossRef]

20. Tsutsumi, A. Size distribution of clasts in experimentally produced pseudotachylytes. J. Struct. Geol. 1999, 21, 305-312. [CrossRef]

21. Anand, R.R.; Gilkes, R.J. Weathering of hornblende, plagioclase and chlorite in meta-dolerite, Australia. Geoderma 1984, 34, 261-280. [CrossRef]

22. Velbel, M.A. Weathering of hornblende to ferruginous products by a dissolution-reprecipitation mechanism: Petrography and stoichiometry. Clays Clay Miner. 1989, 37, 515-524. [CrossRef]

23. Velbel, M.A. Formation of protective surface layers during silicate-mineral weathering under well-leached oxidizing conditions. Am. Mineral. 1993, 78, 405-414.

24. Toy, V.G.; Niemeijer, A.; Renard, F.; Morales, L.; Wirth, R. Striation and slickenline development on quartz fault surfaces at crustal conditions: Origin and effect on friction. J. Geophys. Res.-Sol. Earth 2017, 122, 3497-3512. [CrossRef]

25. Kirkpatrick, J.D.; Rowe, C.D.; White, J.C.; Brodsky, E.E. Silica gel formation during fault slip: Evidence from the rock record. Geology 2013, 41, 1015-1018. [CrossRef]

26. Swanson, M.T. Fault structure, wear mechanisms and rupture processes in pseudotachylite generation. Tectonophysics 1992, 204, 223-242. [CrossRef] 
27. Camacho, A.; Vernon, R.H.; Fitz Gerald, J.D. Large volumes of anhydrous pseudotachylite in the Woodroffe Thrust, eastern Musgraves Ranges, Australia. J. Struct. Geol. 1995, 17, 371-383. [CrossRef]

28. Spray, J.G. Viscosity determinations of some frictionally generated silicate melts: Implications for fault zone rheology at high strain rates. J. Geophys. Res. 1993, 98, 8053-8068. [CrossRef]

29. Bossière, G. Petrology of pseudotachylytes from the Alpine Fault of New Zealand. Tectonophysics 1991, 196, 173-193. [CrossRef]

30. Spray, J.G. Pseudotachylite controversy-Fact or friction? Geology 1995, 23, 1119-1122. [CrossRef]

31. Wallace, R.C. Partial fusion along the Alpine Fault Zone, New Zealand. Geol. Soc. Am. Bull. 1976, 87, 1225-1228. [CrossRef]

32. Killick, A.M. The geochemistry of pseudotachylite and its host rocks from the West Rand Goldfield, Witwatersrand Basin, South Africa: Implications for pseudotachylite genesis. Lithos 1994, 32, 193-205. [CrossRef]

33. Moecher, D.P.; Brearley, A. Mineralogy and petrology of a mullite-bearing pseudotachylyte: Constraints on the temperature of coseismic frictional fusion. Am. Mineral. 2004, 89, 1486-1495. [CrossRef]

34. Spray, J.G. A physical basis for the frictional melting of some rock-forming minerals. Tectonophysics 1992, 205, 19-34. [CrossRef]

35. Di Toro, G.; Pennacchioni, G. Superheated friction-induced melts in zoned pseudotachylytes within the Adamello tonalities (Italian Southern Alps). J. Struct. Geol. 2004, 26, 1783-1801. [CrossRef]

36. Bestmann, M.; Pennacchioni, G.; Frank, G.; Göken, M.; de Wall, H. Pseudotachylyte in muscovite-bearing quartzite: Coseismic friction-induced melting and plastic deformation of quartz. J. Struct. Geol. 2011, 33, 169-186. [CrossRef]

37. Lin, A.; Shimamoto, T. Selective melting processes as inferred from experimentally generated pseudotachylytes. J. Asian Earth Sci. 1998, 16, 533-545. [CrossRef]

38. Lin, A. Glassy pseudotachylite veins from the Fuyun fault zone, northwest China. J. Struct. Geol. 1994, 16, 71-83. [CrossRef]

39. Jiang, H.; Lee, C.-T.; Morgan, J.K.; Ross, C.H. Geochemistry and thermodynamics of an earthquake: A case study of pseudotachylites within mylonitic granitoid. Earth Planet. Sci. Lett. 2015, 430, 235-248. [CrossRef]

40. Beaufort, D.; Patrier, P.; Meunier, A.; Ottaviani, M.M. Chemical variations in assemblages including epidote and/or chlorite in the fossil hydrothermal system of Saint Martin (Lesser Antilles). J. Volcanol. Geotherm. Res. 1992, 51, 95-114. [CrossRef]

41. Ferrow, E.A.; Bagiński, B. Chloritisation of hornblende and biotite: A HRTEM study. Acta Geol. Polonica 1998, 48, 107-113.

42. Saffer, D.M.; Frye, K.M.; Marone, C.; Mair, K. Laboratory results indicating complex and potentially unstable frictional behavior of smectite clay. Geophys. Res. Lett. 2001, 28, 2297-2300. [CrossRef]

43. Van der Pluijm, B.A.; Marshak, S. Earth Structure, 2nd ed.; W.W. Norton \& Company Inc.: New York, NY, USA, 2004; pp. 166-201.

44. Scholz, C.H. The brittle-plastic transition and the depth of seismic faulting. Geol. Rundsch. 1988, 77, 319-328. [CrossRef]

45. Wilson, M.J.; Farmer, V.C. A study of weathering in a soil derived from a biotite-hornblende rock. 11. The weathering of hornblende. Clay Miner. 1970, 8, 435-444. [CrossRef]

46. Zhang, H.; Bloom, P.R.; Nater, E.A. Morphology and chemistry of hornblende dissolution products in acid solutions. Dev. Soil Sci. 1990, 19, 551-556.

47. Inoue, A.; Kurokawa, K.; Hatta, T. Application of chlorite geothermometry to hydrothermal alteration in Toyoha geothermal system, southwestern Hokkaido, Japan. Res. Geol. 2010, 60, 52-70. [CrossRef]

48. Bourdelle, F.; Parra, T.; Chopin, C.; Beyssac, O. A new chlorite geothermometer for diagenetic to low-grade metamorphic conditions. Contrib. Mineral. Petrol. 2013, 165, 723-735. [CrossRef]

49. Maeaudière, J.; Brown, W.L.; Ohnenstetter, D. Microcrystalline textures resulting from rapid crystallization in a pseudotachylite melt in a meta-anorthosite. Contrib. Mineral. Petrol. 1985, 89, 39-51. [CrossRef]

50. Allen, A.R. Mechanism of frictional fusion in fault zones. J. Struct. Geol. 1979, 1, 231-244. [CrossRef]

51. Lin, A. Injection veins of crushing-originated pseudotachylyte and fault gouge formed during seismic faulting. Eng. Geol. 1996, 21, 213-224. [CrossRef]

52. Lin, A. Roundness of clasts in pseudotachylites and cataclastic rocks as an indicator of frictional melting. J. Struct. Geol. 1999, 21, 473-478. [CrossRef] 
53. Magloughlin, J.F. Microstructural and chemical changes associated with cataclasis and friction melting at shallow crustal levels, the cataclasite-pseudotachylite connection. Tectonophysics 1992, 204, 243-260. [CrossRef]

54. Power, W.L.; Tullis, T.E. The relationship between slickenside surfaces in fine-grained quartz and the seismic cycle. J. Struct. Geol. 1989, 11, 879-893. [CrossRef]

55. Chen, X.; Madden, A.S.; Bickmore, B.R.; Reches, Z. Dynamic weakening by nanoscale smoothing during high-velocity fault slip. Geology 2013, 41, 739-742. [CrossRef]

56. Kuo, L.; Song, S.; Suppe, J.; Yeh, E. Fault mirrors in seismically active fault zones: A fossil of small earthquakes at shallow depths. Geophys. Res. Lett. 2016, 43, 1950-1959. [CrossRef]

57. Spray, J.G. Slickenside formation by surface melting during the mechanical excavation of rock. J. Struct. Geol. 1989, 11, 895-905. [CrossRef]

58. Fleuty, M.J. Slikensides and slikenlines. Geol. Mag. 1975, 112, 319-322. [CrossRef]

59. Sibson, R.H.; Toy, V.G. The habitat of fault-generated pseudotachylite: Presence vs. absence of friction-melt. In Earthquakes: Radiated Energy and the Physics of Faulting; American Geophysical Monograph Series 170; Abercrombie, R.E., McGarr, A., di Toro, G., Kanamori, H., Eds.; John Wiley \& Sons, Inc.: Hoboken, NJ, USA, 2006; pp. 153-166.

60. Pec, M.; Stünitz, H.; Heilbronner, R.; Drury, M.; de Capitani, C. Origin of pseudotachylites in slow creep experiments. Earth Planet. Sci. Lett. 2012, 355, 299-310. [CrossRef]

61. Verberne, B.A.; Plümper, O.; Spiers, C.J. Nanocrystalline principal slip zones and their role in controlling crustal fault rheology. Minerals 2019, 9, 328. [CrossRef]

62. Ozawa, K.; Takizawa, S. Amorphous material formed by the mechanochemical effect in natural pseudotachylite of crushing origin: A case study of the Iida-Matsukawa Fault, Nagano Prefecture, Central Japan. J. Struct. Geol. 2007, 29, 1855-1869. [CrossRef]

63. Lee, K.H. Historical earthquake data of Korean. J. Kor. Geophys. Soc. 1998, 1, 3-22.

64. Kyung, J.B.; Chang,T. W. The latest fault movement on the northern Yangsan Fault zone around Yugye-ri area, southeast Korea. J. Geol. Soc. Korea 2001, 37, 563-577.

65. Kyung, J.B. Paleoseismological study and evaluation of maximum earthquake magnitude along the Yangsan and Ulsan Fault Zones in the southeastern part of Korea. Geophys. Geophys. Explor. 2010, 13, 187-197.

66. Kim, K.-H.; Ree, J.-H.; Kim, Y.H.; Kim, S.; Kang, S.Y.; Seo, W. Assessing whether the 2017 Mw 5.4 Pohang earthquake in South Korea was an induced event. Science 2018, 360, 1007-1009. [CrossRef] [PubMed]

67. Kim, K.-H.; Kim, J.; Han, M.; Kang, S.Y.; Son, M.; Kang, T.S.; Rhie, J.; Kim, Y.H.; Park, Y.; Kim, H.-J.; et al. Deep fault plane revealed by high-precision locations of early aftershocks following the 12 September 2016 ML 5.8 Gyeongju, Korea, Earthquake. Bull. Seismol. Soc. Am. 2018, 108, 517-523. [CrossRef]

68. Hong, T.-K.; Lee, J.; Kim, W.; Hahm, I.-K.; Woo, N.C.; Park, S. The 12 September 2016 ML5.8 midcrustal earthquake in the Korean Peninsula and its seismic implications. Geophys. Res. Lett. 2017, 44, 3131-3138. [CrossRef]

69. Fukuyama, E. Introduction: Fault-zone properties and earthquake rupture dynamics. In Fault-Zone Properties and Earthquake Rupture Dynamics; Fukuyama, E., Ed.; Elsevier Academic Press: Burlington, MA, USA, 2009; pp. 1-13.

70. Viti, C.; Brogi, A.; Liotta, D.; Mugnaioli, E.; Spiess, R.; Dini, A.; Zucchi, M.; Vannuccini, G. Seismic slip recorded in tourmaline fault mirrors from Elba Island (Italy). J. Struct. Geol. 2016, 86, 1-12. [CrossRef]

71. Lee, J.; Lee, M.; Choi, J.; Kim, G.; Kim, K. Preliminary analyses of the deep geoenvironmental characteristics for the deep borehole disposal of high-level radioactive waste in Korea. J. Nucl. Fuel Cycle Waste Technol. 2016, 14, 179-188. (In Korean) [CrossRef]

72. Jo, Y.; Chang, C.; Ji, S.-H.; Park, K.-W. In situ stress at KURT, an underground research laboratory in South Korea for the study of high-level radioactive waste disposal. Eng. Geol. 2019, 259, 105198. [CrossRef]

Publisher's Note: MDPI stays neutral with regard to jurisdictional claims in published maps and institutional affiliations. 